3 Saigal S, O'Neill A, Surainder Y, Chua L, Usher R. Placental transfusion and hyperbilirubinemia in the premature. Pediatrics 1972;49:406-19.

4 Saigal S, Usher RH. Symptomatic neonatal plethora. Biol Neonate 1977:32: $62-72$.

5 Linderkamp O. Placental transfusion: determinants and effects. Clin Perinato 1982;9:559-92.

6 von Engel G. Uber den Zeitpunkt der Abnabelung. Zentralblatt für Gynäkologie 1885;9:721-7.

7 Bound JP, Harvey PW, Bagshaw HB. Prevention of pulmonary syndrome of the newborn. Lancet 1962;i:1200-3.

8 Dunn PM. Caesarean section and the prevention of respiratory distress syndrome of the newborn. In: Bossart H, Cruz JM, Huber A, Prdo'hom LS, Sistek J, eds. Perinatal medicine. 3rd European congress of perinatal medicine, Lausanne 1972. Berne: Huber, 1973:138-45.

9 Gilbert R, Keighley JF. The arterial/alveolar oxygen tension ratio. An index of gas exchange applicable to varying inspired oxygen concentrations. Am Rev Respir Dis 1974;109:142-5.

10 Minitab Inc. Reference manual (release 7). Pennsylvania: Minitab, 1989:6-7.

11 Minitab Inc. Reference manual (release 7). Pennsylvania: Minitab, 1989: 7-15.

12 Buckels LJ, Usher R. Cardiopulmonary effects of placental transfusion. f Pediatr 1965;67:239-47.

13 Moss AJ, Monset-Couchard M. Placental transfusion: early versus late clamping of the umbilical cord. Pediatrics 1967;40:109-26.

14 Jones JG, Holland BM, Hudson IRB, Wardrop CAJ. Total circulating red cells versus haematocrit as the primary descriptor of oxygen transport by the blood. Brf Haematol 1990;76:288-94.

15 Dunn PM. The third stage and fetal adaptation. In: Clinch J, Matthews T, eds. Perinatal medicine. 9th European congress on perinatal medicine, Dublin 1984. Lancaster: MTP Press, 1985:47-54.

16 Hofmeyr GJ, Bolton KD, Bowen DC, Govan JJ. Periventricular/intraventricular haemorrhage and umbilical cord clamping. Findings and hypothesis. $S$ Afr Med f 1988;73:104-6.

17 Holland BM, Wardrop CAJ. Anaemias of the preterm infant. In: Turner TL ed. Perinatal haematological problems. Chichester: Wiley, 1991:121-35.

18 Clapp DW, Baley JE, Gerson SL. Gestational age-dependent changes in circulating hematopoietic stem cells in newborn infants. F Lab Clin Med 1989;113:422-7.

19 Fanaroff AA. In: Klaus M, Fanaroff AA, eds. Yearbook of neonatal and perinatal medicine. St Louis: Mosby Yearbook Publishers, 1990:234-5.

20 Inall JA, Bluhm MM, Kerr MM, Douglas TA, Hope CS, Hutchison JH. Blood volume and haematocrit studies in respiratory distress syndrome of the newborn. Arch Dis Child 1965;40:480-4.
21 Brown EG, Krouskop RW, McDonnell FE, Sweet AY. Blood volume and blood pressure in infants with respiratory distress. I Pediatr 1975;87: 1133-8.

22 Usher RH, Saigal S, O'Neill A, Surainder Y, Chua L. Estimation of red blood cell volume in premature infants with and without respiratory distress syndrome. Biol Neonate 1975;26:241-8.

23 Linderkamp O, Versmold HT, Fendel H, Riegel KP, Betke K. Association of neonatal respiratory distress with birth asphyxia and deficiency of red cell mass in premature infants. Eur $\mathcal{F}$ Pediatr 1978;129:167-73.

24 Faxelius G, Raye J, Gutberlet R, Swanstrom S, Tsiantos A, Dolanski E, et al. Red cell volume measurements and acute blood loss in high-risk newborn infants. F Pediatr 1977;90:273-81.

25 Hudson IRB, Holland BM, Jones JG, Turner TL, Wardrop CAJ. First-day total circulating red cell volume (RCV) predicts outcome in preterm infants (PTI) Pediatr Res 1990;27(4) part 2.209A.

26 Moss AJ, Duffie ER, Fagan LM. Respiratory distress syndrome in the newborn-study on the association of cord clamping and the pathogenesis of distress. ҰAMA 1963;184:48-50.

27 Taylor PM, Bright NH, Birchard EL. Effect of early versus delayed clampin of the umbilical cord on the clinical condition of the newborn infant. Am $\mathcal{F}$ Obstet Gynecol 1963;86:893-8.

28 Frank DJ, Gabriel M. Timing of cord ligation and newborn respirator distress. Am f Obstet Gynecol 1967;97:1142-4.

29 Yao AC, Lind J, Tiisala R, Michelsson K. Placental transfusion in the premature infant with observation on clinical course and outcome. Acta Paediatr Scand 1969;58:561-6.

30 Jäykkä S. Capillary erection and the structural appearance of fetal and neonatal lungs. Acta Paediatrica 1958;47:484-500.

31 Gunther $M$. The transfer of blood between baby and placenta in the minutes after birth. Lancet 1957;i:1277-80.

32 Tarnow-Mordi WO, Ogston S, Wilkinson AR, Reid E, Gregory J, Saeed M et al. Predicting death from initial disease severity in very low birthweight infants: a method for comparing the performance of neonatal units. $B M 9$ 1990;300:1611-4.

33 OSIRIS Collaborative Group. Early versus delayed neonatal administration of a synthetic surfactant-the judgement of OSIRIS. Lancet 1992;340:1363-9. 34 Curosurf 4 Study Group. Protocol. Belfast: Queen's University of Belfast, 1990: appendix 1 .

\title{
Comparison of reduction in microalbuminuria by enalapril and hydrochlorothiazide in normotensive patients with insulin dependent diabetes
}

\author{
Magid Hallab, Yves Gallois, Gilles Chatellier, Vincent Rohmer, Philippe Fressinaud, Michel Marre
}

Service de Médecine $B$ and Laboratoire de Biochimie, Centre Hospitalier Universitaire, 49033 Angers, France $M$ Hallab, research fellow, medical service

Yves Gallois, biochemist Vincent Rohmer, professor of medicine

Philippe Fressinaud, professor of medicine Michel Marre, chief physician, medical service and biochemical laboratory

Service d'Informatique Médicale, Hôpital Broussais 75014 Paris, France

Gilles Chatellier, senior registrar

Correspondence to: Dr M Marre, Service de Médecine B, Centre Hospitalier Universitaire, 49033 Angers Cedex 1, France.

$B M \mathcal{J}$ 1993;306: 175-82

\section{Abstract}

Objective-To compare the effects of sodium depletion and of angiotensin I converting enzyme inhibition on microalbuminuria in insulin dependent diabetes.

Design-Randomised, double blind, double dummy parallel study of normotensive diabetic patients with persistent microalbuminuria (30$300 \mathrm{mg} / 24 \mathrm{~h}$ ) treated with enalapril or hydrochlorothiazide for one year after a three month, single blind placebo period.

Setting-Diabetic clinic in a tertiary referral centre.

Patients-10 diabetic patients with low microalbuminuria (30-99 $\mathrm{mg} / 24 \mathrm{~h}$ ) and 11 with high microalbuminuria (100-300 $\mathrm{mg} / 24 \mathrm{~h}$ ).

Interventions-11 subjects (six with low microalbuminuria, five with high microalbuminuria) were given enalapril $20 \mathrm{mg}$ plus placebo hydrochlorothiazide once daily and 10 (four with low microalbuminuria, six with high microalbuminuria) hydrochlorothiazide $25 \mathrm{mg}$ plus placebo enalapri once daily.

Main outcome measures-Monthly assessment of urinary albumin excretion and mean arterial pressure; plasma active renin and aldosterone concentrations and renal function studies at 0,6 , and 12 months.

Results-Median urinary albumin excretion decreased from 59 (range 37-260) to 38 (14-146) $\mathrm{mg} / 24 \mathrm{~h}$ with enalapril and from 111 (33-282) to 109 (33-262) $\mathrm{mg} / 24 \mathrm{~h}$ with hydrochlorothiazide (analysis of variance, $p=0 \cdot 0436$ ). During the last three months of treatment with enalapril five patients had persistent normoalbuminuria (2-3 times below $30 \mathrm{mg} / 24 \mathrm{~h}$ ), five low microalbuminuria, and one high microalbuminuria; in the hydrochlorothiazide group one had normoalbuminuria, three low microalbuminuria, and six high microalbuminuria $\left(\chi^{2}\right.$ test $\left.=6 \cdot 7 ; p=0 \cdot 03\right)$. Mean arterial pressure did not differ before (98 (SD 7) with enalapril $v 97$ (9) $\mathrm{mm} \mathrm{Hg}$ with hydrochlorothiazide) or during treatment $(88(7)$ with enalapril $v$ 90 (7) $\mathrm{mm} \mathrm{Hg}$ with hydrochlorothiazide (analysis of variance, $p=0.5263$ )). Glomerular filtration rate did not vary. The aldosterone to active renin ratio was decreased by angiotensin I converting enzyme inhibition and increased by sodium depletion, showing treatment efficacy.

Conclusion-Angiotensin I converting enzyme inhibition by enalapril effectively reduces microalbuminuria in normotensive diabetic patients whereas hydrochlorothiazide is not effective. Changes in blood pressure and activity of the reninangiotensin-aldosterone system may contribute to these different effects.

\section{Introduction}

Diabetic nephropathy kills many patients with insulin dependent diabetes. ${ }^{\text {' Data }}$ on experimental animals show that it may be the long term consequence of glomerular haemodynamic abnormalities induced by long term hyperglycaemia. Although systemic blood pressure remains normal, glomerular capillary hydraulic pressure becomes raised because of the imbalance between vasodilatation of the vessels before 
the glomerulus and vasoconstriction of those after the glomerulus. ${ }^{2}$ Results in studies of diabetic patients are consistent with this hypothesis.

Persistent microalbuminuria - that is, urinary albumin excretion between normal values and values giving positive results with test strips-predicts diabetic nephropathy and is an early sign of kidney disease. ${ }^{4}$ Intervention trials were performed in normotensive patients with insulin-dependent diabetes and microalbuminuria. Strict glycaemic control by using portable insulin pumps can arrest progression towards diabetic nephropathy, ${ }^{5}$ but this method's safety must be considered in the long term. ${ }^{6}$ A low protein diet is also effective, ${ }^{7}$ but compliance with such a regimen may be a problem. Lastly, we and others have reported that long term treatment with angiotensin I converting enzyme inhibitors can normalise urinary albumin excretion in normotensive diabetic patients with microalbuminuria and prevent diabetic nephropathy.$^{89}$

The decrease in microalbuminuria observed with angiotensin I converting enzyme inhibitors in normotensive diabetic patients ${ }^{89}$ could be the result of inhibition of the renin-angiotensin system's effects on blood pressure or its effect on intraglomerular haemodynamics, or both. It is important to delineate these drugs' mechanisms of action in decreasing urinary albumin excretion in diabetic patients because classic antihypertensive drugs reduce both the rate of progression of diabetic nephropathy" and microalbuminuria in normotensive diabetic patients in the short term. ${ }^{11}$ Therefore, intervention with hypotensive drugs other than angiotensin converting enzyme inhibitors should be considered. In a recent report no difference was found between the effects of perindopril and nifedipine on patients' microalbuminuria and blood pressure over one year. ${ }^{12}$

To discover whether blockade of the renin-angiotensin system by angiotensin I converting enzyme inhibitors contributes to reducing microalbuminuria in normotensive diabetic patients independently of the fall in blood pressure, we compared enalapril's effects on urinary albumin excretion with those of another antihypertensive drug, hydrochlorothiazide, which, unlike enalapril, decreases blood pressure by sodium depletion while stimulating the renin-angiotensin system. ${ }^{13}$ Hydrochlorothiazide is a longstanding antihypertensive drug used as first line treatment in essential hypertension and has also been used safely in normotensive subjects with idiopathic hypercalciuria. ${ }^{14}$ Subclinical sodium retention may be an important feature in insulin treated patients who have diabetic glomerulopathy, even if the renin-angiotensin system activity seems to be normal in such patients. ${ }^{15}$ If sodium retention has an important role in the development of diabetic renal disease a diuretic drug should reduce blood pressure and protect renal function. The primary objective of our study was to compare the changes in microalbuminuria resulting from long term sodium depletion induced by hydrochlorothiazide with those resulting from inhibition of the reninangiotensin system.

\section{Patients and methods \\ PATIENTS}

Patients were selected from a group of 496 patients with insulin dependent diabetes who attended our clinic regularly, according to the following criteria: they were aged 18-60, had insulin dependent diabetes mellitus of at least five years' duration, had a stable body mass index not exceeding $30 \mathrm{~kg} / \mathrm{m}^{2}$, a glycated haemoglobin concentration of less than $10 \%$, were not hypertensive (supine blood pressure less than 160/95 $\mathrm{mm} \mathrm{Hg}$ and no antihypertensive treatment), had persistent microalbuminuria - that is, urinary albumin excretion between 30 and $300 \mathrm{mg} / 24 \mathrm{~h}$ at least twice during the previous six months ${ }^{16}$ - were not pregnant or wanting to be pregnant, and had no chronic disease other than diabetes. Thirty four patients fulfilled these criteria; of these, 25 gave informed written consent to participate in the study. The protocol was approved by the local ethics committee. All patients gave themselves two or more insulin injections daily. Some women took progesterone derivatives as contraception (cases 1, 4, 9, 10, 19, and 23; see table I). No other long term treatment was otherwise taken.

\section{STUDY DESIGN}

After a run in period of three months taking placebo given in a single blind fashion the patients were randomised into two groups by blocks of four using a computer generated random number list. This trial was a parallel, double blind, double placebo trial for one year comparing $20 \mathrm{mg}$ enalapril plus placebo hydrochlorothiazide (enalapril group) with placebo enalapril plus $25 \mathrm{mg}$ hydrochlorothiazide (hydrochloro-

TABLE I-Patients' clinical characteristics at inclusion in study

\begin{tabular}{|c|c|c|c|c|c|c|c|c|c|c|}
\hline $\begin{array}{l}\text { Case } \\
\text { No }\end{array}$ & Sex & $\begin{array}{c}\text { Age } \\
\text { (years) }\end{array}$ & $\begin{array}{c}\text { Diabetes } \\
\text { duration } \\
\text { (years) }\end{array}$ & $\begin{array}{c}\text { Body mass } \\
\text { index } \\
\left(\mathrm{kg} / \mathrm{m}^{2}\right)\end{array}$ & Retinopathy & $\begin{array}{l}\text { Insulin doses } \\
\text { (IU/kg/day) }\end{array}$ & $\begin{array}{c}\text { Glycated } \\
\text { haemoglobin } \\
(\%)\end{array}$ & $\begin{array}{l}\text { Systolic/ } \\
\text { diastolic } \\
\text { pressure } \\
(\mathrm{mm} \mathrm{Hg})\end{array}$ & $\begin{array}{c}\text { Mean } \\
\text { arterial } \\
\text { pressure } \\
(\mathrm{mm} \mathrm{Hg})\end{array}$ & $\begin{array}{c}\text { Urinary } \\
\text { albumin } \\
\text { excretion } \\
(\mathrm{mg} / 24 \mathrm{~h})\end{array}$ \\
\hline \multicolumn{11}{|c|}{ Enalapril } \\
\hline 1 & $\mathrm{~F}$ & 21 & 11 & 23.9 & Background & 0.84 & $9 \cdot 8$ & $128 / 67$ & 88 & 38 \\
\hline 2 & M & 18 & 6 & $20 \cdot 7$ & None & 0.96 & $6 \cdot 9$ & $143 / 78$ & 104 & 48 \\
\hline 3 & $\mathrm{~F}$ & 50 & 16 & $27 \cdot 3$ & Proliferative & 1.01 & $7 \cdot 3$ & $140 / 81$ & 103 & 262 \\
\hline 4 & $\mathrm{~F}$ & 21 & 10 & $25 \cdot 6$ & Background & 0.96 & $7 \cdot 7$ & $125 / 81$ & 92 & 56 \\
\hline 5 & $\mathrm{~F}$ & 50 & 15 & $21 \cdot 3$ & None & 0.56 & $8 \cdot 8$ & $137 / 80$ & 96 & 58 \\
\hline 6 & $M$ & 45 & 15 & $27 \cdot 6$ & Preproliferative & 0.67 & $9 \cdot 8$ & $156 / 84$ & 104 & 252 \\
\hline 7 & M & 57 & 27 & $24 \cdot 3$ & Preproliferative & $0 \cdot 71$ & $8 \cdot 3$ & $123 / 72$ & 91 & 57 \\
\hline 8 & M & 55 & 14 & $27 \cdot 1$ & Background & $0 \cdot 41$ & $5 \cdot 6$ & $148 / 78$ & 98 & 59 \\
\hline $9^{\star}$ & $\mathrm{F}$ & 21 & 18 & $21 \cdot 5$ & None & 1.05 & $9 \cdot 5$ & $114 / 67$ & 79 & 94 \\
\hline $10^{\star}$ & $\mathrm{F}$ & 25 & 14 & $20 \cdot 9$ & None & 1.00 & $7 \cdot 8$ & $111 / 60$ & 74 & 64 \\
\hline 11 & $\mathrm{~F}$ & 28 & 6 & $22 \cdot 6$ & Background & 0.95 & $6 \cdot 7$ & $132 / 84$ & 99 & 136 \\
\hline 12 & $\mathrm{~F}$ & 22 & 14 & 21.9 & None & 0.85 & $8 \cdot 1$ & $137 / 73$ & 91 & 113 \\
\hline 13 & $M$ & 54 & 30 & $26 \cdot 0$ & Background & 0.51 & $7 \cdot 5$ & $149 / 81$ & 99 & 121 \\
\hline \multicolumn{11}{|c|}{ Hydrochlorothiazide } \\
\hline 14 & $M$ & 48 & 15 & $22 \cdot 9$ & Background & 0.93 & $7 \cdot 1$ & $128 / 76$ & 92 & 113 \\
\hline 15 & $M$ & 41 & 20 & $25 \cdot 5$ & Proliferative & $0 \cdot 83$ & $6 \cdot 8$ & $132 / 75$ & 91 & 165 \\
\hline 16 & $M$ & 21 & 7 & $26 \cdot 8$ & None & $0 \cdot 87$ & $9 \cdot 9$ & $132 / 86$ & 94 & 45 \\
\hline 17 & $M$ & 49 & 16 & $27 \cdot 6$ & None & 0.58 & $8 \cdot 3$ & $135 / 75$ & 97 & 34 \\
\hline 18 & $M$ & 20 & 10 & $23 \cdot 8$ & None & 1.00 & $8 \cdot 5$ & $111 / 66$ & 81 & 92 \\
\hline 19 & $\mathrm{~F}$ & 18 & 7 & $22 \cdot 1$ & None & 1.23 & $7 \cdot 8$ & $128 / 74$ & 90 & 148 \\
\hline $20^{\star}$ & $M$ & 50 & 23 & $22 \cdot 6$ & Preproliferative & 0.60 & $7 \cdot 7$ & $159 / 95$ & 117 & 225 \\
\hline $21^{\star}$ & $M$ & 48 & 21 & $20 \cdot 1$ & Preproliferative & 0.51 & $7 \cdot 6$ & $139 / 81$ & 98 & 48 \\
\hline 22 & $M$ & 52 & 9 & $24 \cdot 5$ & None & 0.72 & $7 \cdot 4$ & $114 / 67$ & 81 & 91 \\
\hline 23 & $\mathrm{~F}$ & 30 & 15 & $25 \cdot 1$ & Background & 0.64 & $8 \cdot 0$ & $136 / 93$ & 104 & 223 \\
\hline 24 & $\mathrm{~F}$ & 40 & 7 & $18 \cdot 7$ & None & 0.46 & $8 \cdot 9$ & $124 / 78$ & 91 & 165 \\
\hline 25 & $M$ & 57 & 32 & $23 \cdot 5$ & Proliferative & 0.55 & $7 \cdot 9$ & $154 / 88$ & 106 & 195 \\
\hline
\end{tabular}

^Excluded after six months of treatment. 
thiazide group). Tablets were taken every morning. The doses of $20 \mathrm{mg}$ enalapril and $25 \mathrm{mg}$ hydrochlorothiazide were chosen because they had a similar hypotensive effect in a previous short term pilot study we conducted in diabetic patients with similar characteristics. ${ }^{17}$ The goal of treatment was to lower diastolic blood pressure below $85 \mathrm{~mm} \mathrm{Hg}$. If diastolic blood pressure rose over $85 \mathrm{~mm} \mathrm{Hg}$ after the first three months of active treatment investigators were allowed to double the number of tablets - that is, two tablets of $20 \mathrm{mg}$ enalapril plus two tablets of placebo hydrochlorothiazide, or two tablets of placebo enalapril plus two tablets of $25 \mathrm{mg}$ hydrochlorothiazide. This occurred in cases 2 (enalapril group) and 20 (hydrochlorothiazide group) (see table I). Patients with diastolic blood pressure above $85 \mathrm{~mm} \mathrm{Hg}$ after six months of active treatment were excluded from the study. This occurred in case 20. Tablets were provided by Merck, Sharp, and Dohme and were kept with the randomisation schedule in the hospital pharmacy. Tablets were provided to the patients on each visit. Unused tablets were counted, allowing compliance with treatment to be estimated at greater than $90 \%$ in all patients. At the end of the treatment period the subjects with a persistently normal urinary albumin excretion (less than $30 \mathrm{mg} / 24 \mathrm{~h}$ ) were left untreated and followed up regularly for this variable. Those with urinary albumin excretion above $30 \mathrm{mg} / 24 \mathrm{~h}$ were assigned to $20 \mathrm{mg}$ enalapril per day in an open fashion.

Blood pressure, 24 hour urinary excretion of albumin, sodium, and urea, weight, and insulin doses were recorded every month from the beginning of the run in period to the end of the treatment period. Glycated haemoglobin and plasma electrolyte concentrations were checked every two months. Serum angiotensin I converting enzyme activity and plasma concentrations of renin, aldosterone, lipids, and electrolytes were measured at each renal function studythat is at time 0 and after 6 and 12 months of treatment.

The patients were instructed to follow a constant isocaloric diet (mean 9098 (SD 1574) J/day) composed of $50 \%$ carbohydrate, $35 \%$ lipid, and $15 \%$ protein without any restriction of sodium intake. The same investigator $(\mathrm{MH})$ managed all patients throughout the study.

\section{MEASUREMENTS}

Urinary albumin excretion was measured monthly in 24 hour urine samples by nephelometry ${ }^{18}$ (sensitivity of the assay $0.2 \mathrm{mg} / \mathrm{l}$; intra-assay and interassay variability $4 \%$ and $5 \%$ respectively). Variability in 24 hour urinary albumin excretion within and between subjects was $35 \%$ and $66 \%$ respectively. After log transformation of urinary albumin excretion the variabilities were $8 \%$ and $14 \%$ respectively. We classified each participant as having persistently normal urinary albumin excretion, persistently low microalbuminuria, high microalbuminuria, or macroalbuminuria if at least two of three successive measurements were, respectively, below $30 \mathrm{mg} / 24 \mathrm{~h}$, between 30 and $99 \mathrm{mg} / 24 \mathrm{~h}$, between 100 and $300 \mathrm{mg} / 24 \mathrm{~h}$, or above $300 \mathrm{mg} / 24 \mathrm{~h} .6916$

The systolic, diastolic, and mean arterial pressures were recorded as described previously ${ }^{19}$ with an automatic device (Dinamap, Critikon, Florida; cuff size $23-13 \mathrm{~cm} / 13 \mathrm{~cm}$ ) every three minutes for 30 minutes between 0900 and 1100 while the patient was supine, and the mean of these 10 values was recorded. The variability in mean arterial pressure within and between subjects was $4 \%$ and $6 \%$ respectively. The mean arterial pressure recorded with this device correlated highly with values calculated from mean blood pressure obtained with a mercury sphygmomanometer in the same conditions $(r=0.72 ; \mathrm{p}<0.0001)$.

On the day of the renal function study blood samples were taken from fasted patients who had spent the night supine; serum converting enzyme activity and plasma concentrations of total and active renin and aldosterone were determined. The placebo (time $=0$ ) or active treatment (time $=6$ and 12 months) tablets were then taken after these samplings. Patients were not given their morning insulin. A diuresis of $10-15 \mathrm{ml} / \mathrm{min}$ was induced by progressive water loading, and glomerular filtration rate and effective renal plasma flow were derived, respectively, from the mean clearances of iodothalamate labelled with iodine-125 and hippurate labelled with iodine-131 over six successive 20 minute periods, ${ }^{3}$ as published previously ${ }^{19}$ (median variabilities within subjects and between periods $9 \%$ and $12 \%$ respectively). The filtration fraction was calculated by dividing glomerular filtration rate by effective renal plasma flow, and total renal resistances by dividing the mean arterial pressure (obtained by an automatic device during tracer infusion) by effective plasma flow. Plasma glucose concentrations were recorded as the mean of six determinations by a glucose oxidase method in each sample. Serum albumin concentration was measured by nephelometry, and fractional albumin clearance was calculated by dividing urinary albumin clearance by glomerular filtration rate. Serum angiotensin I converting enzyme activity was measured by Lieberman's method, as modified by Neels et al, ${ }^{20}$ plasma total and active renin values by immunoradiometry, ${ }^{21}$ and plasma aldosterone concentration by radioimmunoassay..$^{22}$ Plasma prorenin concentration was calculated by subtracting active from total renin. Glycated haemoglobin was measured by a high performance liquid chromatography method. ${ }^{23}$ Plasma concentrations of apolipoproteins A1 and B were obtained by nephelometry. Plasma total cholesterol (high density lipoprotein cholesterol after phosphotungstate precipitation), triglyceride, creatinine, potassium, chloride, and uric acid concentrations and plasma and urinary concentrations of urea and sodium were measured by conventional methods.

\section{STATISTICAL ANALYSIS}

Data were stored on an Apple Macintosh II microcomputer and analysed through commercially available statistical software (Statview II, Abacus concepts). Results are presented as means (SD), or medians (ranges) when the distributions were skewed (diabetes duration, urinary albumin excretion, fractional albumin clearance, plasma total and active renin, prorenin, and aldosterone concentrations, and the ratio of active renin to aldosterone concentration). The variables with a skewed distribution were therefore $\log$ transformed for statistical calculation. To analyse changes in urinary albumin and sodium excretion and mean arterial pressure we meaned the values (log transformed for urinary albumin excretion) recorded during the placebo period and during the last three months of follow up. Unpaired $t$ tests were performed to compare two groups. A two way repeated measures analysis of variance was used to evaluate the effects of treatment, of time, and of their interaction on selected variables. When a significant interaction was found between treatment type and time for a given variable, a one way repeated analysis of variance was performed within each treatment group. Correlation coefficients were calculated using the Spearman's non-parametric coefficient. Comparison of two observed distributions was performed with a $\chi^{2}$ test.

The pretrial statistical assumption was that enalapril would be as effective in reducing urinary albumin excretion as was found in a previous one year, placebo controlled study ${ }^{8}$ and that hydrochlorothiazide would not be different from a placebo in such patients. The calculated minimal sample size was eight subjects in each group, with an alpha risk of 0.05 and a beta risk of 
$0 \cdot 10$. As four subjects were excluded from the study after six months of active treatment (see results), we used two methods of analysis. The first was an intention to treat analysis in which the values at the last visit of three pivotal outcome measures-that is, urinary albumin and sodium excretion and mean arterial pressure-obtained from all included subjects during the last three months of their follow up were carried forward. The second was an analysis of treatment given to the 21 subjects who completed the study.

\section{Results}

Thirteen patients were included in the enalapril group and 12 in the hydrochlorothiazide group. Tables I and II show their clinical characteristics. The two groups were strictly similar for all variables, especially for initial blood pressure and urinary albumin excretion. Two patients from each group were excluded from the study after six months of active treatment. In the enalapril group two patients (cases 9 and 10) (both initially with low microalbuminuria) decided to withdraw from the trial because they wished to become pregnant (at withdrawal both displayed persistent normoalbuminuria, which persisted after stopping experimental treatment). In the hydrochlorothiazide group one patient (case 20) (initially with high microalbuminuria) developed high blood pressure not controlled after six months of treatment (he still had high microalbuminuria at this time), and he was therefore excluded according to the protocol. Another (case 21) lost $10 \mathrm{~kg}$ in weight because of severe depression and was therefore withdrawn from the study. $\mathrm{He}$ was initially classified as having low microalbuminuria and remained so at withdrawal. With the intention to treat analysis, mean urinary albumin excretion was 62 $(38-260) \mathrm{mg} / 24 \mathrm{~h}$ in the enalapril group during placebo v $112(33-283) \mathrm{mg} / 24 \mathrm{~h}$ in the hydrochlorothiazide group $(\mathrm{p}=0.3546)$. It declined to $29(11-146) \mathrm{mg} / 24 \mathrm{~h}$ with enalapril but was $109(12-267) \mathrm{mg} / 24 \mathrm{~h}$ with hydrochlorothiazide during the last three months of follow up $(p=0.0087)$. Mean arterial pressure was similar between groups during placebo $(97$ (8) $\mathrm{mm} \mathrm{Hg}$ in enalapril group $v 97$ (8) $\mathrm{mm} \mathrm{Hg}$ in hydrochlorothiazide group; $\mathrm{p}=0.996)$ and also at the end of follow up (89 (8) $\mathrm{mm} \mathrm{Hg}$ in enalapril group $v 93$ (10) $\mathrm{mm} \mathrm{Hg}$ in hydrochlorothiazide group; $\mathrm{p}=0 \cdot 2613)$. Urinary sodium excretion was comparable between groups during placebo $(164(59) \mathrm{mmol} / 24 \mathrm{~h}$ in enalapril group v $158(62) \mathrm{mmol} / 24 \mathrm{~h}$ in hydrochlorothiazide group; $\mathrm{p}=0 \cdot 8092)$, but higher with hydrochlorothiazide than enalapril at end of follow up (142 (56) $\mathrm{mmol} / 24 \mathrm{~h} v 197$ (73) $\mathrm{mmol} / 24 \mathrm{~h} ; \mathrm{p}=0.0469$ ).

The following analysis by treatment was performed on the 11 patients in the enalapril group and the 10 in the hydrochlorothiazide group who completed the study. The groups remained comparable (tables I and II). Figure 1 shows the individual changes in urinary albumin excretion with time and treatment. During the placebo period urinary albumin excretion was similar in the two groups (analysis of variance, $\mathrm{p}=0.324$ ) but significantly lower during treatment with enalapril than with hydrochlorothiazide (analysis

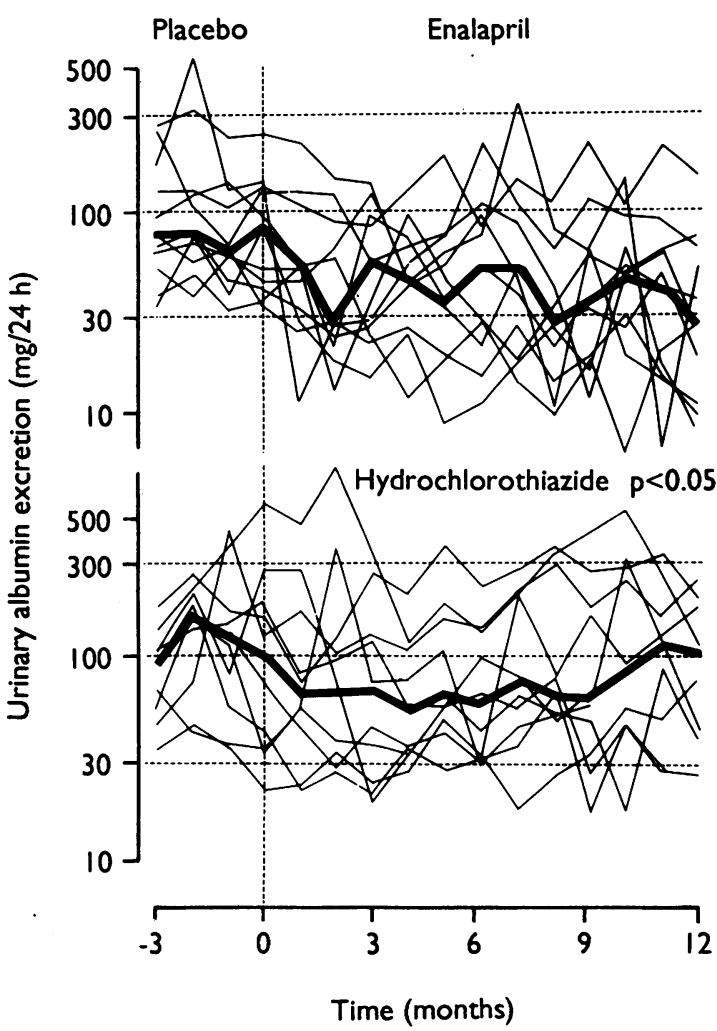

FIG 1-Individual plots of urinary albumin excretion in 11 normoten sive diabetic patients with microalbuminuria treated with enalapril $20 \mathrm{mg}$ per day (upper panel) and of 10 others treated with hydrochlorothiazide $25 \mathrm{mg}$ per day (lower panel) for one year. Thick lines indicate median values for each group. See text for statistical analysis.

of variance, treatment type effect, $p=0.0436$ ). During the placebo period five patients in the enalapril group displayed persistent high microalbuminuria and the six others low microalbuminuria, compared with six patients with high microalbuminuria and four with low microalbuminuria in the hydrochlorothiazide group $\left(X^{2}=1.9 ; \mathrm{p}>0 \cdot 3\right)$. During the last three months of treatment five patients taking enalapril displayed a persistent normoalbuminuria, five a low microalbuminuria, and one a high microalbuminuria, whereas in the hydrochlorothiazide group one patient had persistent normoalbuminuria, three low microalbuminuria, and six high microalbuminuria $\left(\chi^{2}=6 \cdot 7\right.$; $\mathrm{p}=0.03)$. With enalapril urinary albumin excretion declined from 59 (37-260) $\mathrm{mg} / 24 \mathrm{~h}$ during placebo to 38 (14-146) $\mathrm{mg} / 24 \mathrm{~h}$ during the last three months of study, while it varied from $111(33-282)$ to $109(33-262) \mathrm{mg} /$ $24 \mathrm{~h}$ with hydrochlorothiazide. Thus, the median difference in urinary albumin excretion reduction was $-57 \mathrm{mg} / 24 \mathrm{~h}(95 \%$ confidence interval 15 to 114$)$ in favour of enalapril. Urinary albumin excretion was reduced by $20 \%$ ( -50 to 10 ) with enalapril at the end of follow up $v 2 \%$ ( -36 to 32 ) with hydrochlorothiazide $(\mathrm{p}=0.0176)$.

Mean arterial pressure was not different between the two groups during the placebo period 98 (7) $\mathrm{mm} \mathrm{Hg}$ in enalapril group $v 97(9) \mathrm{mm} \mathrm{Hg}$ in hydrochlorothiazide group; $p=0.9004$ ) or during the whole treatment

TABLE II-Mean (SD) and median values for clinical characteristics in 25 patients enrolling in study and in the 21 completing it

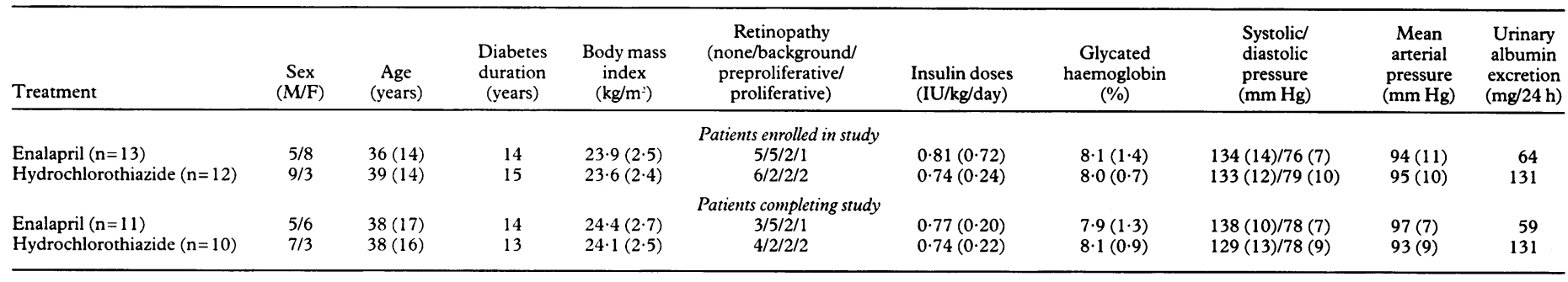




\begin{tabular}{|c|c|c|c|c|c|c|c|}
\hline & & \multicolumn{3}{|c|}{ Time (months) } & \multicolumn{3}{|c|}{$\mathrm{p}$ Value } \\
\hline & & 0 & 6 & 12 & Treatment & Time & Interaction \\
\hline $\begin{array}{l}\text { Glomerular filtration rate } \\
\left(\mathrm{ml} / \mathrm{min} / 1 \cdot 73 \mathrm{~m}^{2}\right)\end{array}$ & $\left\{\begin{array}{l}\text { Enalapril } \\
\text { Hydrochlorothiazide }\end{array}\right.$ & $\begin{array}{l}143(23) \\
141(35)\end{array}$ & $\begin{array}{l}134(36) \\
134(32)\end{array}$ & $\begin{array}{l}133(27) \\
132(32)\end{array}$ & $0 \cdot 86$ & 0.09 & 0.90 \\
\hline $\begin{array}{l}\text { Effective renal plasma flow } \\
\left(\mathrm{ml} / \mathrm{min} / 1 \cdot 73 \mathrm{~m}^{2}\right)\end{array}$ & $\left\{\begin{array}{l}\text { Enalapril } \\
\text { Hydrochlorothiazide }\end{array}\right.$ & $\begin{array}{c}609(93) \\
628(142)\end{array}$ & $\begin{array}{l}615(162) \\
583(111)\end{array}$ & $\begin{array}{l}596(166) \\
588(152)\end{array}$ & 0.90 & 0.51 & 0.55 \\
\hline Filtration fraction & $\left\{\begin{array}{l}\text { Enalapril } \\
\text { Hydrochlorothiazide }\end{array}\right.$ & $\begin{array}{l}0.2371(0.0219) \\
0.2271(0.0322)\end{array}$ & $\begin{array}{l}0.2273(0.0325) \\
0.2308(0.0316)\end{array}$ & $\begin{array}{l}0.2284(0.0245) \\
0.2285(0.0291)\end{array}$ & 0.84 & $0 \cdot 80$ & 0.54 \\
\hline $\begin{array}{l}\text { Total renal resistance } \\
(\mathrm{mm} \mathrm{Hg} / \mathrm{ml} / \mathrm{min})\end{array}$ & $\left\{\begin{array}{l}\text { Enalapril } \\
\text { Hydrochlorothiazide }\end{array}\right.$ & $\begin{array}{l}0.1672(0.0332) \\
0.1604(0.0462)\end{array}$ & $\begin{array}{l}0.1547(0.0557) \\
0.1631(0.0446)\end{array}$ & $\begin{array}{l}0.1663(0.0942) \\
0.1745(0.0898)\end{array}$ & 0.88 & 0.06 & 0.72 \\
\hline $\begin{array}{l}\text { Median (range) fractional } \\
\text { albumin clearance }\left(\times 10-^{\circ}\right)\end{array}$ & $\left\{\begin{array}{l}\text { Enalapril } \\
\text { Hydrochlorothiazide }\end{array}\right.$ & $\begin{array}{c}7 \cdot 1(3 \cdot 7-46 \cdot 1) \\
14 \cdot 0(4 \cdot 1-46 \cdot 2)\end{array}$ & $\begin{array}{l}5 \cdot 6(1 \cdot 2-20 \cdot 9) \\
6 \cdot 4(3 \cdot 9-74 \cdot 2)\end{array}$ & $\begin{array}{c}4 \cdot 8(1 \cdot 5-22 \cdot 5) \\
13 \cdot 5(3 \cdot 7-98 \cdot 9)\end{array}$ & $0 \cdot 10$ & 0.002 & 0.02 \\
\hline Plasma glucose $(\mathrm{mmol} /)^{\star}$ & $\left\{\begin{array}{l}\text { Enalapril } \\
\text { Hydrochlorothiazide }\end{array}\right.$ & $\begin{array}{l}12 \cdot 8(4 \cdot 6) \\
10 \cdot 5(5 \cdot 1)\end{array}$ & $\begin{array}{r}\cdot 12 \cdot 0(2 \cdot 9) \\
10 \cdot 8(5 \cdot 1)\end{array}$ & $\begin{array}{l}11 \cdot 5(3 \cdot 3) \\
10 \cdot 5(4 \cdot 7)\end{array}$ & 0.39 & $0 \cdot 64$ & 0.66 \\
\hline
\end{tabular}

* Mean of six values measured during renal function studies.

period (88 (7) $\mathrm{mm} \mathrm{Hg}$ in the enalapril group and 90 (7) $\mathrm{mm} \mathrm{Hg}$ in the hydrochlorothiazide group; $\mathrm{p}=0.5263$ ) (fig 2 ). The mean intergroups difference in mean arterial pressure was $-1 \mathrm{~mm} \mathrm{Hg}(7$ to -9$)$ during the last three months of follow up. Baseline values were comparable between groups for the urinary excretions
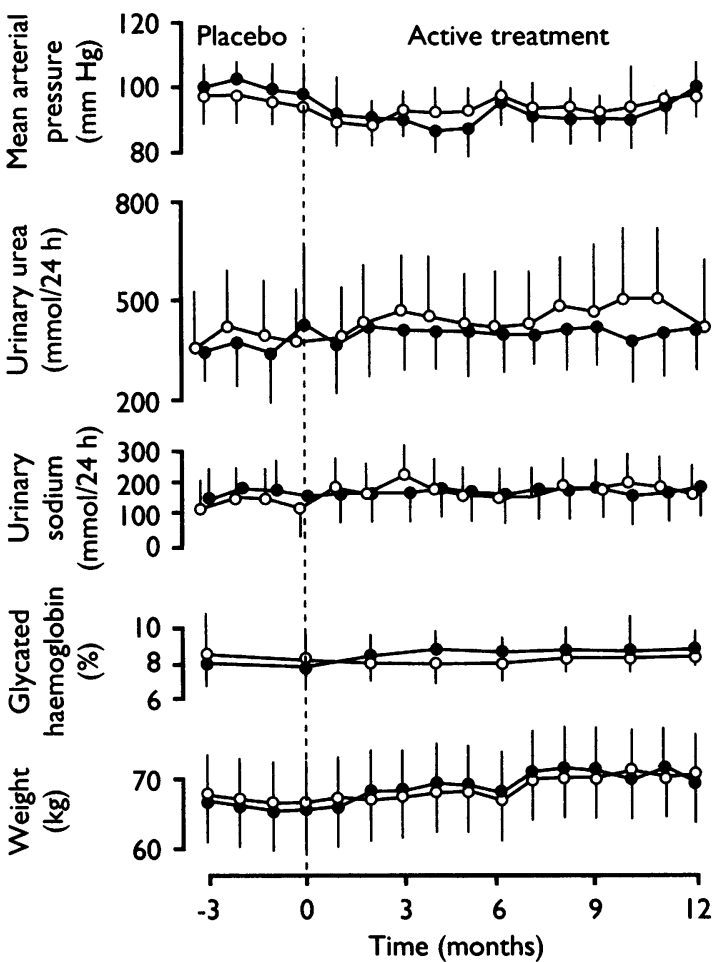

FIG 2-Change in mean arterial pressure, urinary urea and sodium excretion, glycated haemoglobin concentration, and weight during the study in enalapril group (i) $(n=11)$ and hydrochlorothiazide group (O) $(n=10)$. Results are means; bars indicate SD. See text for statistical analysis.
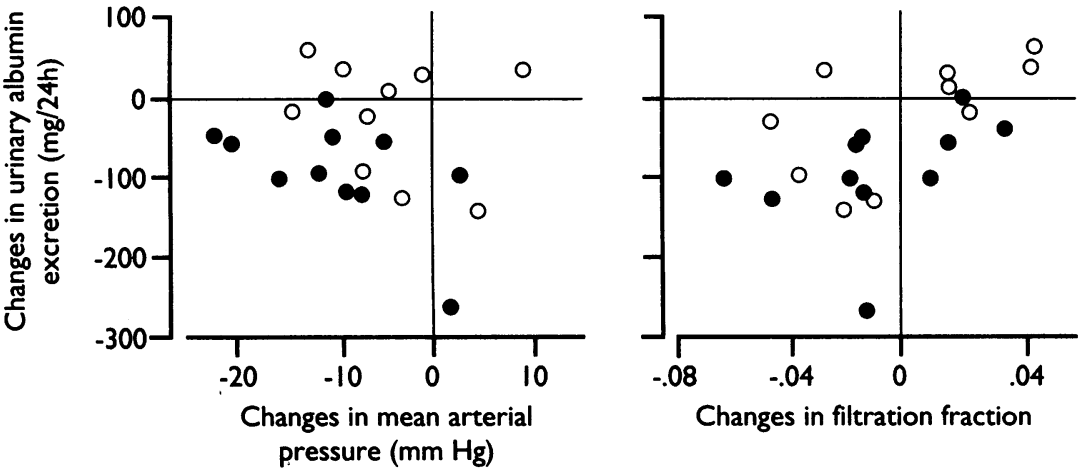

FIG 3-Correlations between changes in urinary albumin excretion and changes in mean arterial pressure and in filtration fraction in normotensive diabetic subjects with microalbuminuria treated with $20 \mathrm{mg}$ enalapril per day (O) or $25 \mathrm{mg}$ hydrochlorothiazide per day $(\mathrm{O})$ from inclusion to the last three months of study. See text for statistical analysis. of urea $(p=0.3785)$ and sodium $(p=0.8454)$, for glycated haemoglobin concentration $(p=0.7299)$, and for weight $(p=0.8524)$. During the treatment period groups remained comparable for urinary urea excretion $(p=0 \cdot 7526)$, for glycated haemoglobin concentration $(p=0.4447)$, and for weight $(p=0.8524)$, but urinary sodium excretion was slightly higher with hydrochlorothiazide than enalapril (analysis of variance, treatment type effect, $p=0 \cdot 0809$ ) (fig 2).

Table III shows renal function in the two groups at times 0,6 , and 12 months. No significant alteration of glomerular filtration rate, effective renal plasma flow, total renal resistances, or filtration fraction was observed between or within the groups. Conversely, fractional albumin clearance fell with both treatments from 0 to 6 months (although not significantly) but then rose to pretreatment values after 12 months with hydrochlorothiazide, whereas it fell further with enalapril (one way analysis of variance of the treatmenttime interaction for enalapril group, $p=0.022$ ). Plasma glucose concentrations did not differ between the two groups.

The rate of progression of urinary albumin excretion from the placebo period to the last three months of follow up was positively related to the difference between filtration fractions at time 0 and time 12 months $\left(r^{\prime}=0.50, \mathrm{p}=0.026\right.$ for all patients; $r^{\prime}=0.48$ for enalapril group; $r^{\prime}=0.54$ for hydrochlorothiazide group) (fig 3, right panel). However, the rate of progression of urinary albumin excretion was not correlated to the progression of mean arterial pressure recorded at the corresponding times $\left(r^{\prime}=-0 \cdot 23\right.$, $\mathrm{p}=0.302$ for all patients; $r^{\prime}=-0.24$ for enalapril group; $r^{\prime}=-0.20$ for hydrochlorothiazide group) (fig 3 , left panel). Urinary albumin excretion progression was not related to changes in urinary sodium and urea excretion, glycated haemoglobin concentration, or weight, but it was related to the sum of urinary sodium excretion during the whole treatment period $\left(r^{\prime}=0.44\right.$, $\mathrm{p}=0.05$ for all patients; $r^{\prime}=0.39$ for enalapril group; $r^{\prime}=0.36$ for hydrochlorothiazide group).

At baseline plasma prorenin was higher and the ratio of active renin to prorenin concentration lower in the subjects included in the study than in 22 controls of comparable age (426 (449) $\mathrm{ng} / \mathrm{l} v 207(75) \mathrm{ng} / \mathrm{l}(\mathrm{p}=0.04)$ and $0.040(0.046) \quad v \quad 0.126(0.047)$ respectively, $(p=0.0012))$. Plasma prorenin concentrations were related to the degree of retinopathy before active treatment $\left(r^{\prime}=0.51, \mathrm{p}=0.026 ; \mathrm{n}=21\right)$. Serum angiotensin I converting enzyme activity was reduced by enalapril but did not change with hydrochlorothiazide. Plasma active and total renin and prorenin concentrations rose with both types of treatment but the ratio of active renin to prorenin concentration was higher with enalapril than hydrochlorothiazide. Plasma aldosterone concentration was increased by hydrochlorothiazide but did not change significantly with enalapril. The ratio of aldosterone to active renin concentration was 


\begin{tabular}{|c|c|c|c|c|c|c|c|}
\hline & & \multicolumn{3}{|c|}{ Time (months) } & \multicolumn{3}{|c|}{$\mathrm{p}$ Value } \\
\hline & & 0 & 6 & 12 & Treatment & Time & Interaction \\
\hline $\begin{array}{l}\text { Serum angiotensin I } \\
\text { converting enzyme (IU/I) }\end{array}$ & $\left\{\begin{array}{l}\text { Enalapril } \\
\text { Hydrochlorothiazide }\end{array}\right.$ & $\begin{array}{l}350(241-512) \\
351(222-608)\end{array}$ & $\begin{array}{l}221(172-286) \\
377(248-720)\end{array}$ & $\begin{array}{l}205(146-366) \\
379(207-709)\end{array}$ & 0.006 & 0.0015 & 0.0001 \\
\hline Plasma active renin (ng/l) & $\left\{\begin{array}{l}\text { Enalapril } \\
\text { Hydrochlorothiazide }\end{array}\right.$ & $\begin{array}{l}11(5-22) \\
14(7-35)\end{array}$ & $\begin{array}{c}35(5-240) \\
23(5-53)\end{array}$ & $\begin{array}{l}45(5-89) \\
21(5-51)\end{array}$ & 0.44 & 0.0001 & 0.0025 \\
\hline Plasma total renin $(\mathrm{ng} / \mathrm{l})$ & $\left\{\begin{array}{l}\text { Enalapril } \\
\text { Hydrochlorothiazide }\end{array}\right.$ & $\begin{array}{c}275(70-855) \\
385(95-2020)\end{array}$ & $\begin{array}{l}643(167-1340) \\
520(115-2726)\end{array}$ & $\begin{array}{c}650(215-1338) \\
436(55-2503)\end{array}$ & 0.75 & 0.0001 & 0.021 \\
\hline Plasma prorenin (ng/l) & $\left\{\begin{array}{l}\text { Enalapril } \\
\text { Hydrochlorothiazide }\end{array}\right.$ & $\begin{array}{c}263(65-845) \\
367(88-1985)\end{array}$ & $\begin{array}{l}583(135-1302) \\
486(110-2673)\end{array}$ & $\begin{array}{c}605(207-1312) \\
411(50-2452)\end{array}$ & 0.79 & 0.0001 & 0.026 \\
\hline Active renin/prorenin & $\left\{\begin{array}{l}\text { Enalapril } \\
\text { Hydrochlorothiazide }\end{array}\right.$ & $\begin{array}{l}0.04(0.09-0.01) \\
0.04(0.08-0.01)\end{array}$ & $\begin{array}{l}0.06(0.33-0.02) \\
0.05(0.14-0.02)\end{array}$ & $\begin{array}{l}0.07(0.20-0.02) \\
0.06(0.11-0.02)\end{array}$ & 0.51 & 0.016 & 0.017 \\
\hline Plasma aldosterone (ng/l) & $\left\{\begin{array}{l}\text { Enalapril } \\
\text { Hydrochlorothiazide }\end{array}\right.$ & $\begin{array}{l}109(20-206) \\
97(19-220)\end{array}$ & $\begin{array}{c}95(28-347) \\
160(50-360)\end{array}$ & $\begin{array}{l}146(41-225) \\
178(79-314)\end{array}$ & 0.44 & 0.035 & $0 \cdot 184$ \\
\hline Active renin/aldosterone & $\left\{\begin{array}{l}\text { Enalapril } \\
\text { Hydrochlorothiazide }\end{array}\right.$ & $\begin{array}{l}0 \cdot 10(0.03-1 \cdot 50) \\
0.21(0.04-0 \cdot 74)\end{array}$ & $\begin{array}{l}0.34(0.03-2 \cdot 15) \\
0.14(0.06-0.51)\end{array}$ & $\begin{array}{l}0.33(0.04-0.64) \\
0.12(0.05-0.43)\end{array}$ & $0 \cdot 3987$ & 0.0062 & 0.0004 \\
\hline $\begin{array}{l}\text { Mean (SD) plasma uric } \\
\text { acid }(\mu \mathrm{mol} / \mathrm{l})\end{array}$ & $\left\{\begin{array}{l}\text { Enalapril } \\
\text { Hydrochlorothiazide }\end{array}\right.$ & $\begin{array}{l}260(93) \\
264(73)\end{array}$ & $\begin{array}{l}252(96) \\
315(88)\end{array}$ & $\begin{array}{c}258(106) \\
319(92)\end{array}$ & 0.35 & 0.001 & 0.0001 \\
\hline
\end{tabular}

decreased by enalapril but increased by hydrochlorothiazide (table IV)

Plasma uric acid concentration rose with hydrochlorothiazide but not enalapril (table IV). Plasma concentrations of electrolytes and creatinine, lipid variables, and daily insulin doses remained steady throughout the study (not shown).

No clinical side effect was observed throughout the study.

\section{Discussion}

Effective renin-angiotensin system blockade with enalapril, shown by the fall in serum angiotensin I converting enzyme activity and the rise in plasma active renin concentration without changes in plasma aldosterone concentration, significantly reduced the microalbuminuria of normotensive diabetic patients within one year of treatment. Conversely, the sodium depletion induced by a low dose of hydrochlorothiazide, shown by the rise in plasma uric acid, active renin, and aldosterone concentrations, did not reduce microalbuminuria after one year's treatment.

Our study design explains how we could detect a significant difference in urinary albumin excretion between two treatments in a small number of subjects for a short period of time: monthly measurements over 12 months increased the precision and consequently the power of our trial. Biased measurements were avoided by appropriate blinding and automated blood pressure measurements. Serum angiotensin I converting enzyme activity and monitoring of plasma renin and aldosterone concentrations suggests that patients were compliant with their assigned treatments.

The Melbourne Diabetic Nephropathy Study Group did not find a difference in urinary albumin excretion between nifedipine and perindopril in a one year randomised study including 53 patients with type 1 or type 2 diabetes with or without hypertension. ${ }^{12}$ However, this study was open and only two urine collections were used to assess albumin excretion at baseline and after 12 months. Mathiesen et al found a difference in urinary albumin excretion between captopril and no antihypertensive treatment by measuring blood pressure and urinary albumin excretion every four months in 44 patients similar to ours, but this was true only after four years of follow up. ${ }^{9}$ This result could be explained by the absence of a fall in blood pressure between as well as within groups. Also, baseline urinary sodium excretion was higher in the patients studied by Mathiesen $e t a l^{9}$ than it was in our current and previous patients. ${ }^{8}$ Sodium intake may modulate both the hypotensive and the renal responses to angiotensin I converting enzyme inhibitors. ${ }^{24}$ Our finding of an association between urinary albumin and sodium excretion may explain why angiotensin I converting enzyme inhibition seemed more effective in reducing microalbuminuria in our studies than in theirs. ${ }^{9}$

Confounding variables which may have affected urinary albumin excretion were similar within and between our two groups - that is, glycaemic control, weight, and protein intake (as reflected by urinary urea excretion). Mean arterial pressure was the most important variable to adjust for between the two groups. During this trial, five of the 11 patients taking enalapril were normoalbuminuric after one year of treatment, while mean arterial pressure decreased by $10 \mathrm{~mm} \mathrm{Hg}$. These results are almost identical with those obtained during a previous trial comparing the same drug, used at the same dose over the same time period, with placebo. ${ }^{8}$ In our current study the reduction in microalbuminuria was observed only with enalapril, even though blood pressure was lowered in hydrochlorothiazide treated patients. However, our study cannot exclude that enalapril and hydrochlorothiazide had different hypotensive effects, because to detect a difference of $5 \mathrm{~mm} \mathrm{Hg}$ between the two groups, with $90 \%$ power, would have required 191 patients in each group. Hydrochlorothiazide's ineffectiveness in reducing microalbuminuria could be explained by two possibilities. Firstly, the hypotensive effect of this drug may not have been of sufficient size to reduce microalbuminuria. Secondly, the activation of the renin-angiotensin system (the physiological consequence of sodium depletion) may have had opposite intrarenal effects to those of angiotensin I converting enzyme inhibition, and therefore microalbuminuria was not reduced, even though blood pressure was reduced by hydrochlorothiazide treatment. Our observations that the drop in urinary albumin excretion correlated with the changes in filtration fraction but not with the drop in blood pressure are consistent with the second possibility. This result agrees with those reported by Anderson et al in rats with streptozotocin induced diabetes: hypotension induced by captopril was more effective than that induced by a classic triple treatment to prevent a rise in urinary albumin excretion.

The relation between decreased urinary albumin excretion and changes in filtration fraction is consistent with the hypotheses of a predominant role of glomerular haemodynamic alterations in producing microalbuminuria in insulin dependent diabetes and also of the decisive role of the reduction in intraglomerular capillary pressure mediated by angiotensin I converting inhibitors in the antialbuminuric effects of these compounds. Angiotensin II has been shown to increase glomerular capillary hydraulic pressure. ${ }^{26}$ At baseline, the renin component characteristics in the studied 
subjects were consistent with those depicted in other studies $^{192}$ : active renin concentration was normal, but prorenin concentration was raised according to retinopathy. Prorenin concentration increased proportionally less than active renin concentration with enalapril than with hydrochlorothiazide, which suggests that juxtaglomerular cell stimulation with enalapril was ineffective. Plasma aldosterone concentration decreased compared with active renin concentration with enalapril but increased with hydrochlorothiazide. A possible short term reduction of microalbuminuria due to hydrochlorothiazide's hypotensive effect may have been progressively counterbalanced by the effective renin-angiotensin-aldosterone system stimulation provoked by the same drug.

The precise mechanism of enalapril's antialbuminuric effects is not elucidated by the present study. The predominant role of intraglomerular capillary pressure reduction is supported by the correlation between changes in urinary albumin excretion and in filtration fraction, but filtration fraction did not vary, a finding consistent with previous reports. 819282930 Angiotensin I converting enzyme inhibitors may act in reducing glomerular basement membrane pore size. ${ }^{31}$

Reference hypotensive drug choice may be critical when comparing other hypotensive drugs with angiotensin I converting enzyme inhibitors in reducing microalbuminuria in normotensive diabetic subjects. Metoprolol was the first drug shown to be effective for this purpose, ${ }^{32}$ but the role of reduced renin secretion induced by this $\beta$ blocker was not delineated. In advanced diabetic nephropathy Björk et al reported that enalapril reduced proteinuria more effectively than metoprolol, while the hypotensive effect of both drugs was similar. ${ }^{33} \beta$ Blockers may be less effective than angiotensin I converting enzyme inhibitors in reducing microalbuminuria because they are less effective in reducing angiotensin II production. Studies comparing calcium antagonists with angiotensin I converting enzyme inhibitors are controversial. In the short term captopril reduced microalbuminuria more effectively than nifedipine in subjects with incipient diabetic nephropathy. ${ }^{34} 35$ The Melbourne Diabetic Nephropathy Study Group found no difference over one year between perindopril and nifedipine in reducing microalbuminuria and blood pressure. ${ }^{12}$ However, a $\beta$ type error cannot be excluded in this study because the prestudy assumption was that microalbuminuria progression was exclusively pressure dependent. Calcium antagonists can modify renal haemodynamics; consequently, trials comparing angiotensin I converting enzyme inhibitors with calcium antagonists should be based on differences in their renal effects estimated from previous trials in insulin dependent diabetic subjects. ${ }^{36}$

Finally, different antihypertensive drugs' appropriateness for the impaired renal function of diabetic subjects should be determined by their differences concerning clinically relevant end points-for example, difference in the rate of deterioration in the glomerular filtration rate. We showed that enalapril prevented such deterioration in normotensive diabetics with microalbuminuria compared with placebo. ${ }^{8}$ Here, no difference was observed between enalapril and hydrochlorothiazide on the glomerular filtration rate; however this study's design (conceptualised exclusively for studying microalbuminuria) does not allow such a difference to be ruled out. In previous long term trials with glycaemic control intervention the change in microalbuminuria was an accurate reflection of the change in glomerular filtration rate. ${ }^{56}$ If microalbuminuria is an appropriate surrogate end point that could replace glomerular filtration rate changes in clinical trials, one can anticipate that enalapril will protect glomerular filtration rate better than hydro- chlorothiazide in the long term. In this connection Björk et al reported that enalapril protected glomerular filtration rate more effectively than metoprolol in diabetic nephropathy after four years of follow up. ${ }^{37}$

Normotensive diabetic subjects with microalbuminuria may exhibit a reduced glomerular filtration rate and hypertension secondary to glomerular disease very rapidly in the absence of intervention..$^{69}$ Therefore, it is timely to compare angiotensin I converting enzyme inhibitors with other antihypertensive drugs on glomerular filtration rate in a representative sample of normotensive patients with insulin dependent diabetes and persistent microalbuminuria.

This study was supported by grants from Merck, Sharp and Dohme and from the University of Angers. We thank Joël Menard from the Service de Médecine Préventive CardioVasculaire, Hôpital Broussais, Paris, for his warm support and useful advice throughout the study; Françoise Bled and Andrée Girault-Louvel from this biochemical laboratory; Patrick Gillabert and Jean-Jacques Lejeune from Médecine Nucléaire et Biophysique, Angers; Stéphane Schnebeeli from Centre Hospitalier, Lorient; Tam-Tam Guyenne from Hôpital Broussais, Paris, for warm support and technical help; Brigitte Chevet from this medical service for technical help; Martin Day from Hôpital Broussais, Paris, for editorial help; and Line Godiveau for excellent secretarial help.

1 Andersen AR, Christiansen JS, Andersen JK, Kreiner S, Deckert T. Diabetic nephropathy in type 1 (insulin-dependent) diabetes: an epidemiological study. Diabetologia 1983;2:496-501.

2 Hostetter TH, Troy $\Omega$, Brenner BM. Glomerular hemodynamics in experimental diabetes mellitus. Kidney Int 1981;19:410-5.

3 Mogensen CE. Glomerular filtration rate and renal plasma flow in short-term and long-term juvenile diabetes mellitus. Scand f Clin Lab Invest 1971;28: 91-100.

4 Mogensen CE. Prediction of clinical diabetic nephropathy in IDDM patients: alternatives to microalbuminuria? Diabetes 1990;39:761-7.

5 Feldt-Rasmussen B, Mathiesen ER, Deckert T. Effect of two years of stric metabolic control on progression of incipient nephropathy in insulindependent diabetes. Lancet 1986;ii:1300-4.

6 Feldt-Rasmussen B, Mathiesen ER, Jensen T, Lauritzen T, Deckert T. Effect of improved metabolic control on loss of kidney function in type 1 (insulindependent) diabetic patients: an update of the Steno studies. Diabetologia 1991;34:164-70.

7 Cohen D, Dodds R, Viberti GC. Effect of protein restriction in insulindependent diabetics at risk of nephropathy. $B M \mathcal{F}$ 1987;294:795-8.

8 Marre M, Chatellier G, Leblanc H, Guyenne TT, Menard J, Passa P. Prevention of diabetic nephropathy with enalapril in normotensive diabetics with microalbuminuria. BM7 1988;297:1092-5.

9 Mathiesen ER, Hommel E, Giese J, Parving HH. Efficacy of captopril in postponing nephropathy in normotensive insulin dependent diabetic patients with microalbuminuria. BMY 1991;303:81-7.

10 Mogensen CE. Long-term antihypertensive treatment inhibiting progressio of diabetic nephropathy. $B M 7$ 1982;285:685-8.

11 Hommel E, Mathiesen ER, Edsberg B, Bahnsen M, Parving HH. Acute reduction of arterial blood pressure reduces urinary albumin excretion in type I (insulin-dependent) diabetic patients with incipient nephropathy. Diabetologia 1986;29:211-5.

12 Melbourne Diabetic Nephropathy Study Group. Comparison between perindopril and nifedipine in hypertensive and normotensive diabetic patients with microalbuminuria. BMf 1991;302:210-6.

13 Keeton T, Campbell WB. The pharmacological alterations of renin release. Pharmacol Rev 1980;32:81-227.

14 Sutton RAL, Walker VR. Responses to hydrochlorothiazide and acetazolamide in patients with renal stones: evidence suggesting a defect in renal tubula function. N Engl I Med 1980;302:709-13.

15 Feldt-Rasmussen B, Mathiesen E, Deckert T, Giese J, Christensen NJ, BentHansen L, et al. Central role for sodium in the pathogenesis of blood pressure changes independent of angiotensin, aldosterone and catecholamines in type 1 (insulin-dependent) diabetes mellitus. Diabetologia 1987;30:610-7.

16 Mogensen CE, Chachati A, Christensen CK, Close CF, Deckert T, Hommel E, et al. Microalbuminuria: an early marker of renal involvement in diabetes. Uremia Investigation 1985-6;9:85-95.

17 Marre $M$, Leblanc $H$, Passa $P$. Effets rénaux à court terme d'une baisse de la pression artérielle chez des diabétiques ayant une néphropathie débutante. Diabète et Métabolisme 1987;13:480.

18 Marre M, Claudel JP, Ciret P, Luis N, Suarez L, Passa P. Laser immunonephelometry for routine quantification of urinary albumin excretion. Clin Chem 1987;33:209-13.

19 Marre M, Leblanc H, Suarez L, Guyenne TT, Menard J, Passa P. Converting enzyme inhibition and kidney function in normotensive diabetic patients enzyme inhibition and kidney function in normotensive
with persistent microalbuminuria. BMf 1987;294:1448-52.

20 Neels HM, Van Sande ME, Scharpe SL. Sensitive colorimetric assay for angiotensin converting enzyme in serum. Clin Chem 1983;29:1399-403.

21 Menard J, Guyenne TT, Corvol P, Pau B, Simon D, Roncucci R. Direc immunometric assay of active renin in human plasma. $f$ Hypertens 1985 3(suppl 3):275-8

22 Pham Huu Trung MT, Corvol P. A direct determination of plasma aldosterone. Steroids 1974;24:587-98.

23 Goldstein DE, Little RR, England JD, Wiedmeyer HM, McKenzie EM. Methods for quantitating glycosylated hemoglobins: high-performance liquid chromatography and thiobarbituric acid colorimetry. In: Clarke WL Lamer J, Pohl SL, eds. Methods in diabetes research. Vol 2. Clinical methods. Lamer J, Pohl SL, eds. Methods

24 MacGregor GA, Markandu ND, Smith SJ, Sagnella GA, Morton JA. 
Angiotensin converting enzyme inhibition reveals an important role for the Anin system in the control of normal and high blood pressure in man. Clin Exp Hypertens [A] 1983;5:1367-80.

25 Anderson S, Rennke HG, Garcia DL, Brenner BM. Short and long term effects of antihypertensive therapy in the diabetic rat. Kidney Int 1989;36: 526-36.

26 Hall JE, Guyton AC, Jackson TE, Coleman TG, Lohmeier TE, Tripoddo NC. Control of glomerular filtration rate by renin-angiotensin system. Am $\mathcal{f}$ Physiol 1977;233:F366-72.

27 Franken AAM, Derkx FHM, Man in't Veld, Hop WCJ, van Rens GH, Peperkamp E, et al. High plasma prorenin in diabetes mellitus and its correlation with some complications. I Clin Endocrinol Metab 1990;71: 1008-15.

28 Marre M, Hallab M, Billiard A, Le Jeune JJ, Bled F, Girault A, et al. Small doses of ramipril to reduce microalbuminuria in diabetic patients with incipient nephropathy independently of blood pressure changes. f Cardiovasc Pharmacol 1991:18:S165-8.

29 Pedersen MM, Schmitz A, Pedersen EB, Danielsen H, Christiansen JS. Acute and long-term renal effects of angiotensin converting enzyme inhibition in normotensive, normoalbuminuric insulin-dependent diabetic patients. Diabetic Med 1988;5:562-9.

30 Rudberg S, Aperia A, Freyschuss U, Persson B. Enalapril reduces microalbuminuria in young normotensive type 1 (insulin-dependent) diabetic patients irrespective of its hypotensive effect. Diabetologia 1990;33:470-6.
31 Morelli E, Loon N, Meyer T, Peters W, Myers BD. Effects of converting enzyme inhibition on barrier function in diabetic glomerulopathy. Diabetes 1990;39:76-82.

32 Christensen CK, Mogensen CE. Effect of antihypertensive treatment on progression of incipient diabetic nephropathy. Hypertension 1985;7 (suppl II):109-13.

33 Björk S, Mulec H, Hohnsen SA, Nyberg G, Aurell M. Contrasting effects of enalapril and metoprolol on proteinuria in diabetic nephropathy. $B M F$ 1990;300:904-7.

34 Mimram A, Insua A, Ribstein J, Bringer J, Monnier L. Comparative effects of captopril and nifedipine in normotensive patients with incipient diabetic nephropathy. Diabetes Care 1988:11:850-3.

35 Romanelli G, Giustina A, Bossoni S, Caldonazzo A, Cimino A, Cravarezza P, et al. Short-term administration of captopril and nifedipine and exerciseinduced albuminuria in normotensive diabetic patients with early-stage nephropathy. Diabetes 1990;39:1333-8.

36 Hannedouche T, Delgado A, Gnionsahe A, Boitard C, Lacour B, Grunfeld JP. Renal hemodynamics and segmental tubular reabsorption in early type 1 diabetes. Kidney Int 1990;37:1126-33.

37 Björck S, Mulec H, Johnson SA, Norden G, Aurell M. Renal protective effect of enalapril in diabetic nephropathy. BMF 1992;304:339-43.

(Accepted 30 October 1992)

\title{
Epidemiology of endometriosis in women attending family planning clinics
}

\author{
M P Vessey, L Villard-Mackintosh, R Painter
}

\section{Abstract}

Objective-To describe the epidemiology of endometriosis in women attending family planning clinics with special reference to contraceptive methods.

Design-Non-randomised cohort study with follow up of subjects for up to 23 years. Disease was measured by first hospital admission rates since endometriosis can be diagnosed with accuracy only at laparotomy or laparoscopy.

Setting-17 family planning centres in England and Scotland.

Subjects-17032 married white women aged 25-39 years at entry during 1968-74 who were taking oral contraceptives or using an intrauterine device or diaphragm. About $99 \%$ of the women approached agreed to participate and annual loss to follow up was about $0 \cdot 3 \%$.

Main outcome measures-Diagnosis of endometriosis, age, parity, and history of contraceptive use.

Results-Endometriosis was significantly related to age, peaking at ages $40-44\left(\chi^{2}\right.$ for heterogeneity= $30.9, p<0.001)$. Endometriosis was not linked to duration of taking oral contraceptives. Nevertheless, the risk of endometriosis was low in women currently taking oral contraceptives (relative risk $0.4 ; 95 \%$ confidence interval 0.2 to 0.7 ), but higher in women who had formerly taken them $(1 \cdot 8 ; 1.0$ to 3.1 in women who had stopped 25-48 months previously) compared with women who had never taken the pill. A similar pattern was seen for use of intrauterine devices (relative risk $0.4(0.2$ to 0.7$)$ in current users and $1.4(0.4$ to 3.2$)$ in users $49-72$ months previously compared with never users). No association was found between endometriosis and use of the diaphragm.

Department of Public Health and Primary Care, Radeliffe Infirmary, Oxford OX2 6HE

M P Vessey, professor

L Villard-Mackintosh, research officer

R Painter, computer scientist

Correspondence to:

Professor Vessey.

Conclusions-Oral contraceptives seem to temporarily suppress endometriosis. Endometriosis may be diagnosed late in women using intrauterine devices as pain and bleeding occur with both.

\section{Introduction}

Endometriosis is a condition in which there is functioning endometrial tissue outside the uterine cavity.' The disease process is usually limited to the pelvis and clinical manifestations include pain, menstrual disorders, infertility, and pelvic masses. Diagnosis by clinical methods is unreliable and confirmation is required by laparoscopy or laparotomy.

In view of the lack of epidemiological information about endometriosis, we decided to analyse the available data in the Oxford Family Planning Association contraceptive study.

\section{Subjects and methods}

The methods used in the Oxford Family Planning Association study have been described in detail elsewhere. ${ }^{2}$ In brief, 17032 women were recruited at 17 large family planning clinics in England and Scotland during 1968-74. To be eligible for the study women had to be white, British, married, aged 25-39 years, and to have been taking oral contraceptives for at least five months, or using a diaphragm or intrauterine device for at least five months without previous exposure to oral contraceptives. About $99 \%$ of those approached consented to participate in the study and follow up is still continuing.

At return visits to the clinic women are questioned by a doctor or a nurse and the information recorded on a special form, including details of pregnancies and their outcome, changes in contraceptive practices, and reasons for referral to hospital. Women who stop attending the clinic are sent a postal version of the questionnaire and, if this is not returned, are interviewed over the telephone or at a home visit. Each hospital admission is followed up by writing to the consultant concerned to obtain a copy of the discharge summary. The work in each clinic is coordinated by a part time research assistant, and follow up has been maintained with an annual loss because of withdrawal of cooperation or loss of contact of only about $0.3 \%$. Only women who have never taken the pill and those who have taken it for eight or more years are followed up beyond the age of 45 .

The study collects detailed morbidity information only about illnesses requiring referral to hospital. This was not a limitation in this analysis because endometriosis has to be diagnosed by laparoscopy or laparotomy. The numbers of cases per 1000 woman years of observation in the various groups were compared. Rates of first diagnosis for endometriosis within these groups were standardised by the indirect method. ${ }^{2}$ 